\title{
Prostitutes and Urban Communities of Medieval Slavonia: Examples from Gradec
}

\author{
Marija Karbić \\ Department of History of Slavonia, Syrmia and Baranya, \\ Croatian Institute of History, Croatia, mkarbic@isp.hr
}

\begin{abstract}
The focus of this paper is the position of prostitutes in urban settlements of medieval Slavonia, a part of the medieval Kingdom of Hungary. The following questions are discussed: which social group did prostitutes come from, what possible reasons led a woman to become a prostitute, were prostitutes involved in the other types of criminal activities, how were prostitutes organized, in which part of the city were prostitutes situated, and what do we know about their customers? The research shows that prostitution was not limited only to members of the lowest layer of society and people on the margins, and that there existed a certain tolerance towards prostitution.
\end{abstract}

Keywords: prostitutes; urban settlements; Kingdom of Hungary; Slavonia; Gradec; legal regulations; judicial practice; Middle Ages 


\title{
Prostitutes and Urban Communities of Medieval Slavonia: Examples from Gradec
}

\author{
Marija Karbić \\ Croatian Institute of History, Croatia
}

\section{Introduction}

As the editors of this volume have correctly pointed out, most of the scholarship on medieval women focuses on those who played some distinguished role in society rather than those on the margins. In order to answer this question of who these "other" women were in the Middle Ages (and how they may be conceptualized as "others"), this contribution aims at providing insight into the position of prostitutes in the urban settlements of medieval Slavonia (present-day north-western Croatia), a part of the medieval Kingdom of Hungary. In doing so, the first task is to provide some background on the life of these prostitutes. This study focuses on the free royal city of Gradec (part of modern-day Zagreb) because the source material for its history is more abundant and diverse than for the other settlements in this area. ${ }^{1}$

While judicial records comprise the main body of primary source material, other written sources that reflect everyday life (i.e. city protocols, property documents) will also be consulted here.

The aim of this paper is to answer the following questions: from which social group did prostitutes come from, what possible reasons led a woman to become a prostitute, was prostitution a main profession or just an additional source of income for the women in question, were

\footnotetext{
* This work has been supported in part by the Croatian Science Foundation under the project "Towns and Cities of the Croatian Middle Ages: Urban Elites and Urban Space", no. IP-2014-09-7235.

${ }^{1}$ Historical records of medieval Gradec (Zagreb) are published in Ivan Krstitelj Tkalčić, Povjestni spomenici slob. kralj. grada Zagreba. Monumenta historica liberae regiae civitatis Zagrabiae (henceforth: MCZ), vol. 1-11 (Zagreb: Grad Zagreb, 1889-1905).
} 
prostitutes involved in other types of criminal activities, how were prostitutes organized, were there official city brothels and if so where in the city were they situated?

\section{Who were prostitutes?}

First, we can see that the prostitutes in Gradec were mostly widows and unmarried girls. For example, Dorothy (Dora) Kuhinačić, widow of Martin Kranjec, was banished after found engaging in prostitution in 1461 (and soon after pardoned), ${ }^{2}$ while in 1499 another woman named Dorothy, the daughter of Cosmas, is mentioned as a prostitute (meretrix). ${ }^{3}$ In 1465, Elisabeth, daughter of Matejčić, Jalšica, daughter of Tančec, and Margaret, widow of George Zvonar, were all banished because of prostitution. ${ }^{4}$ However, in some cases prostitutes could also be married women. One interesting example was recorded in 1454 . Several women were punished for engaging in prostitution, including four married women: Jalšica, wife of Cosmas, Mayhena, wife of tailor Stephan, Margaret, wife of shoemaker Lacko, and Elisabeth, wife of George Krčmarić. It is noteworthy that Elisabeth's daughter Catherine was apprehended as well. ${ }^{5}$

Among prostitutes, we can find women from all sorts of different social groups. Some of them were women from the lowest layer of society and from a criminal milieu who were involved in various different crimes. For example, a certain mulier publica Anne is mentioned in the court records of 1460, when she had her ear cut off because she had stolen a towel and a pillow from the wife of Tančec. In addition, the same Anne is mentioned in the same record stating that Elisabeth, wife of Stephan known as Ćuk (the Owl), paid her one golden florin to burn down the houses of Kelec, a boot-maker, and his neighbour, Clement. For these reasons, Anne was banished from the city after being beaten; she was forbidden to return. ${ }^{6}$ Among prostitutes who were also involved in other criminal activities, we may count a certain Granda who, after being expelled from the city with her husband for

\footnotetext{
${ }^{2}$ MCZ, vol. 7, 208, 212.

${ }^{3} M C Z$, vol. 8, 127-128.

${ }^{4} M C Z$, vol. 7, 270.

${ }^{5} M C Z$, vol. 7,73 .

${ }^{6} M C Z$, vol. 7, 192.
} 
stealing, returned to the city in secrecy. Then, she was caught in meretricio with a priest named Martin of Ivanić and was expelled once again. ${ }^{7}$ This lowest layer of prostitutes also included girls who came into the city from its surroundings without the protection of their families or some profession to provide a steady source of income; as a result, they became prostitutes. One of them was the aforementioned Dorothy, daughter of Cosmas, who came to Gradec from Otok, a village in its environs (de Othok). ${ }^{8}$

Nevertheless, prostitution did not just involve women from the lowest layer of society. Dorothy, widow of Martin Kranjec, is mentioned by the city magistrate as concivis nostra, meaning that she was a full-right citizen, a member of the leading layer within the urban population. ${ }^{9}$ As the example from 1454 shows, there were also wives of different artisans (although the less prominent ones) among the prostitutes. While this may seem surprising at first, in these cases, the women in question viewed prostitution not a main profession but rather an additional source of income.

${ }^{7}$ MCZ, vol. $7,323,325-326$.

$8 M C Z$, vol. 8, 127-8.

${ }^{9}$ Citizens (cives) enjoyed economic and other privileges given to the city which were denied to other denizens. Male citizens had the right to elect and to be elected as a city magistrate and to participate via the city council as tota communitas in making important decisions for the city. Besides citizens (cives), Gradec also recognized inhabitants (inhabitatores) and lodgers (inquilini). The difference between these two groups was determined by possession of real estate. Namely, inhabitatores possessed real estate while inquilini did not. Among inhabitatores, there were members of different social layers, from noblemen (which included magnates and members of lesser nobility) through rich newcomers to poor craftsmen and petty traders. Members of this group satisfied the preliminary conditions to be accepted among citizens - that is they possessed real estate in the city - but they either did not satisfy other preconditions (to live irreproachably in the city for at least a year, be Christian, make application for receiving status of citizen, pay tax, and swear an oath) or simply did not have interest for it for some unknown reason. Inquilini were, in most cases, hired labourers who worked either in the city or as agricultural workers within the urban territory. They lived in houses owned by citizens, frequently five, six or seven of them together. For more, see: Nada Klaić, Zagreb $u$ srednjem vijeku [Zagreb in the Middle Ages] (Zagreb: Sveučilišna naklada Liber, 1982), 216-220; Magdalena Apostolova Maršavelski, Iz pravne prošlosti Zagreba (13.-16. stoljéce) [From the legal history of Zagreb] (Zagreb: Školska knjiga, 1998), 161-172. 
In Gradec and other urban settlements of medieval Slavonia, prostitution cannot be connected with any specific part of the city. ${ }^{10}$ Mentions of prostitutes are rare and thus it is not possible to pinpoint the location of houses where they worked or lived. Furthermore, city regulations that would have localised them in some area did not exist, since in principle they were not allowed to operate anywhere. ${ }^{11}$ After all, it seems that they often operated in the houses of their customers. The sources mention girls that wandered through the city and the district who entered the houses of bachelors. In the lawsuits against them, the witnesses were often city guards who reported on movements that they had noticed during the night. ${ }^{12}$ Regarding the question of whether Gradec had any official municipal brothel in the Middle Ages, some women kept prostitutes in their houses (more will be said on that later), but it seems there were no brothels in the full sense of word. There was never a place denoted by some particular term and it seems these women operated in private houses (either their own or that of someone else).

\section{The attitude towards prostitution}

In urban settlements of medieval Slavonia, prostitution was considered a great evil. This negative attitude towards prostitution is evidenced by the fact that calling a woman a prostitute (meretrix) or a man the son of a prostitute was one of the biggest possible insults. Law suits originating from these kinds of insults are mentioned frequently in court records. In 1441, Ursula, the wife of Clemens called Buhweth,

\footnotetext{
${ }^{10}$ Connection between prostitution and certain city quarters can be found in urban settlements in different areas of Europe. For example, in Dubrovnik, the prostitutes mainly operated in the part of the city called Castelleto. Cf. G. Ravančić, "Prostitucija u kasnosrednjo-vjekovnom i renesansnom Dubrovniku" [Prostitution in late medieval and Renaissance Dubrovnik], in Gradske marginalne skupine u Hrvatskoj kroz srednji vijek $i$ ranomoderno doba [Urban marginal groups in Croatia in the Middle Ages and the early modern period], Biblioteka Dies historiae, vol. 1 (Zagreb: Hrvatski studiji, 2004), 95; Gordan Ravančić, "Prostitution in Late Medieval Dubrovnik", in this volume.

11 The regulations which localised prostitution in some areas of the town are mentioned in numerous urban settlements. For example, for London, see: Ruth Mazo Karras, Prostitution and Sexuality in Medieval England (New York - Oxford: Oxford University Press, 1996), 15. These rules existed in certain Dalmatian cities as well. For instance, in Split. Cf. Ravančić, "Prostitucija," 94.

$12 M C Z$, vol. 7, xx.
} 
accused the wife of an agricultural worker named Bartholomew of calling her a prostitute, ${ }^{13}$ while in 1466 , the merchant Pero was accused of telling the wife of Phister that she was a prostitute. ${ }^{14}$ Similar insults may also be found in quarrels among respected members of Gradec society, including members of the city magistrate. In 1475, juror Thomas, son of Francis, called the former judge Valentine an old dog and the son of prostitute (antiquus canis et filius meretricis). ${ }^{15}$ Since such statements were considered to be a great insult, the punishments were grave as well. When Kate, widow of Janko, accused Benedict Magyar of insulting her by calling her a prostitute of monks, priests, and hundred thieves (meretrix monachorum et presbiterorum ac centum latronum), she proved her allegations with witnesses; Benedict was thus sentenced to pay homagium vivum. ${ }^{16}$ Similar insults are also found within families. Anne, the wife of juror Peter, son of Thomas, proved in court that her brother, Stephan, had called her a prostitute and concubine of Vuk, the tax collector. As a result of this, Stephan was sentenced to pay homagium. ${ }^{17}$

Negative attitudes towards prostitution within the urban settlements of medieval Slavonia are also confirmed by the fact that the punishment for engaging in prostitution was banishment from the city. Since the individual's existence was seriously threatened by losing the protection of the community, his or her property in the city, and a way to sustain himself or herself, this punishment was only implemented in cases of serious crimes. As previously mentioned, a similar punishment occurred in 1461, to Dorothy Kuhinačić, widow of Martin Kranjec. After being caught several times engaging in prostitution (propter maliciosum opus concubinatus sepius reperta fuit et desistere noluit et manifeste reperta fuit), she was banned from the city. ${ }^{18}$ However, it should be said

\footnotetext{
${ }^{13} M C Z$, vol. 6, 347.

${ }^{14} \mathrm{MCZ}$, vol. 7, 309.

${ }^{15} \mathrm{He}$ did this while refusing to pay a tax on wine. $M C Z$ vol. $7,438-439$.

${ }_{16} \mathrm{MCZ}$, vol. 8, 95. Homagium vivum was a sum of money, which was owed by a person who killed, maimed, or otherwise harmed a man or woman and paid to the victim or his/her family. For more, see: János M. Bak, György Bónis, James Ross Sweeney, Leslie S. Domonkos, The Laws of the Medieval Kingdom of Hungary. Decreta regni mediaevalis Hungariae, vol. 1 (Idyllwild: Charles Schlacks, Jr., Publisher, 1999), 141, s. v. composition (compositio).

${ }^{17} M C Z$, vol. 6, 346.

18 MCZ, vol. 7, 208, 212.
} 
that Dorothy was pardoned at the request of many people (as the record states), and this pardon was not an exception. Women convicted for engaging in prostitution were frequently pardoned either immediately or after some time had passed. This was the case in 1465 when Dorothy Kuhinačić, Barbara the Lame, Elisabeth, daughter of Matejčić, Jalšica, daughter of Tančec, Margaret, widow of George Zvonar, and Helen Mezonosična were sentenced to banishment from the city and subsequently pardoned. ${ }^{19}$ Even though they were warned at that time that they will be banished if caught again, the case itself shows that pardon might be received even in cases of recidivism. Namely, Dorothy Kuhinačić who was sentenced and pardoned at that occasion had, as already mentioned, been convicted of prostitution several years prior and pardoned. Pardon was also given to prostitutes from the lowest echelons of society. ${ }^{20}$ An example of this happening is the aforementioned case of Granda, who was banished from the city after being caught in meretricio with the priest Martin of Ivanić; ${ }^{21}$ she was pardoned in 1369.22

The punishment connected with prostitution could be even more severe than banishment from the city. In the aforesaid case from 1454, a whole group of women was punished for engaging in prostitution. They were caught in manifesto meretricio et pluribus maleficiis. Thus, they were supposed to be punished "according to their merits," but they were pardoned at the request of many noble and honourable men; instead, they were merely banned from the city. ${ }^{23}$ The nature of the original punishment was not stated, but it is probable that it was the death penalty since banishment from the city was perceived as a lighter and reduced punishment. Such a severe punishment may be explained by the fact that the accused were married women. Besides engaging in

\footnotetext{
${ }^{19}$ MCZ, vol. 7, 270 .

${ }^{20}$ For more details on the social stratification of medieval Gradec, see: Klaić, Zagreb $u$ srednjem vijeku, 216-229, 248-264; Apostolova Maršavelski, Izpravne prošlosti, 163-172; S. Miljan, "Siromasi kasnosrednjovjekovnoga Zagreba" [The poor of late-medieval Zagreb] Povijesni prilozi 42 (2012): 81-102.

${ }_{21}$ MCZ, vol. 7, 323, 325-326.

22 MCZ, vol. 7, 358.

$23 \mathrm{MCZ}$, vol. 7, 73 .
} 
prostitution, they had committed adultery as well; according to the legal practice of Gradec, the prescribed punishment was death. ${ }^{24}$

It is important to highlight that pardoning and reducing the sentence was the usual practice in Gradec (as well as in other towns of medieval Slavonia), and this practice was not specifically connected with prostitution. Therefore, it would be wrong to assume that the "honourable and noble men" who spoke on behalf of the plaintiffs were actually their customers. The reasons which led to such a practice could be debated. It could be that mercy was a virtue accentuated in the Christian world or the fact that the inhabitants of these cities were mutually bound with various ties - of family or neighbourhood - or even the practical problem of the difficulty of hiring executioners. In any case, showing mercy was not a rarity in these urban settlements.

Two case studies regarding prostitutes receiving pardons are worth mentioning here, even though the pardons were not connected to prostitution itself. The first case refers to the pardon of a prostitute sentenced for infanticide, that is, abortion. Dorothy, daughter of Cosmas, was sentenced to death by drowning in the river Sava because of committing the abortion. She confessed that she is the murderer of two of her children, whom she squashed within her womb and then made them to exit from her already dead, but she was pardoned by the plea of the executioner Valentine who wished to marry her. ${ }^{25}$ In another case, it was a man who was pardoned. In 1462, the bell-ringer Paul was sentenced to death because he took part in a theft. He was pardoned when mulier publica Jelka, together with "many respectful and honorable women," came before the court and stated that she would become his lawfully wedded wife. ${ }^{26}$ These decisions of the city court reflect the intention of securing peaceful life in the city. If it was possible to establish order without punishment, it was better to find an alternate solution; after all, such punishments could disquiet the

\footnotetext{
${ }^{24} \mathrm{On}$ the attitudes towards adultery in the cities of the interamnium, see M. Karbić, "The 'Illicit Love' in Medieval Slavonian Cities," in Love, Marriage and Family Ties in the Middle Ages, ed. Isabel Davis, Miriam Müller, Sarah Rees, International Medieval Research 11 (Turnhout: Brepols, 2003), 331-340.

25 "quod est paricida duarum prolium suarum, quos in se per vim oppressit et mortuos de se exire fecit ". $M C Z$, vol. 8, 127-128.

${ }^{26} M C Z$, vol. 7, 224-225.
} 
community which had connections to those penalized. ${ }^{27}$ Contracting a marriage was considered as a guarantee that an individual would behave more responsibly in the future, according to the norms of society. ${ }^{28}$

In addition to punishing prostitution, sources from the Slavonian cities also show attempts to prevent it. In 1378, the city council forbade a young widow to go into the Chapter area (Kaptol), specifically ordering that she should not enter houses there. If, as the source mentions, she "would be caught in evil," the city authorities would then confiscate her property and banish her. It should also be noted that soon afterwards, this decision of the city magistrate was rescinded and because of "the plea of an honourable man which restored her initial civil freedom." 29

The attitudes of certain communities on certain issues can be revealed in some way through legal regulations, with the necessary precaution that there is a difference between legal ideals and practices. Unfortunately, the statutes of Slavonian cities (including Gradec) are extant only in later versions from the seventeenth century onwards. ${ }^{30}$ Nevertheless, Gradec was a tavernical city, that is, one of the free royal cities to whom the court of appeal on decisions of city magistrates was the court presided over by a special royal officer called Master of the Treasury (magister tavernicorum). It is thus possible to compare it with the statute of Ilok/Újlak, a city in the eastern part of Sava and Drava interamnium. ${ }^{31}$ Its regulations are not specific regulations for Ilok, but regulations that were applicable to all so-called tavernical cities. ${ }^{32}$ Since

${ }^{27}$ For a similar attitude of city authorities in cases of adultery, see: Karbić, "The 'Illicit Love' in", 338-340.

28 Similar reasoning is confirmed by, for example, a regulation of the guild of tailors mentioned in the Law book of Ilok according to which a new guild member had to, together with some honest men, provide sureties that he will lawfully wed in the course of one year and become a father of a family. (Ilockei statut, 84).

${ }^{29} M C Z$, vol. 5, xxx, 144 .

${ }^{30}$ For the oldest statute of Gradec, see: Vjekoslav Klaić, Statut grada Zagreba od 1609. $i$ njegova reforma god. 1618. [The Statute of the City of Zagreb of 1609 and its Reform of 1618] (Zagreb: Grad Zagreb, 1912).

${ }^{31}$ For Gradec as part of the group of tavernical cities, see: Apostolova Maršavelski, Iz pravne proslosti, 25.

32 For more on tavernical law and the cities, see Štefánia Mertanová, Ius tavernicale: stúdie o procese formovania práva tavernickych miest v etapách vívoja taverniickeho súdu v Uhorsku (15.-17. stor.) [Ius tavernicale: Studies on the formation process of the law of tavernical cities through the stages of development of the tavernical court in Hungary $\left(15^{\text {th }}-17^{\text {th }}\right.$ 
Gradec was a tavernical city, it may be presumed that similar rules were applied here as well and including data from Ilok would provide a more complete picture. Furthermore, the similarities of lifestyle and social structure as well as human and business relations and exchanges of population indicate that similar legislation was also applied to other Slavonian urban settlements.

The previously-discussed negative attitude toward prostitution is confirmed in the regulations of the law book of Ilok. There, one finds severe condemnation for a mother leading her daughter into prostitution. It is the same article that deals with the murder of an illegitimate child, where it states that a woman who leads her daughter into prostitution should be treated like a woman who has killed her illegitimate child - that is, she should be burned. ${ }^{33}$ The link between those two activities can be explained with the understanding that in both cases the point in question is killing one's own child. In the first case the child's body was killed while in the second case its soul.

According to the statute of Ilok, those who led girls or young women into fornication would also be severely punished. Those persons were to be shackled and then "sunk in deep water." This would be done regardless of whether they were doing it for money or out of

centuries)] (Bratislava: Slovenskej Akademie Vied, 1985); Lujo Margetić, Hrvatsko srednjovjekovno obiteljsko $i$ nasljedno pravo [Croatian medieval family and inheritance law] (Zagreb: Narodne novine, 1996), 286-87; T. Shek Brnardić, “Tavernik, tavernikalni sud i tavernikalno pravo" [Tavernicus, tavernical court and tavernical law], Arbivski vjesnik 40 (1997): 179-98. On the statute of Ilok see Andrija Zdravčević, "Iločki statut iz 1525. godine i njegova nasljednopravna regulacija" [The statute of Ilok from 1525 and its hereditary-legal regulation], PhD Thesis (Osijek: Pravni fakultet, 1992); L. Margetić, "Iločka pravna knjiga (tzv. Iločki statut)" [Ilok's law book (the so-called statute of Ilok)], Zbornik Pravnog fakulteta u Zagrebu 44/1-2 (1994): 93-116; Darko Vitek, "Društveni odnosi u srednjovjekovnom Iloku prikazani Iločkim statutom iz 1525. godine" [The social relations in medieval Ilok according to the statute of Ilok from 1525], MA Thesis (Zagreb: Filozofski fakultet, 2000); idem, "Struktura i izvorište teksta Iločkog statuta" [The structure and origin of the text of the statute of Ilok], Scrinia Slavonica 1 (2001): 404-20. The statute of Ilok was published by Rudolf Schmidt, Statut grada Iloka iz godine 1525 [The statute of the city of Ilok from the year 1525] (henceforth: Ilockei statut), Monumenta historico-juridica Slavorum Meridionalium, vol. 12 (Zagreb: JAZU, 1938).

33 This is stated in the book 3, ch. 15. entitled De mulieribus, que prolem in adulterio susceptam interfecerint, et que propriam filiam suam ad prostibulum tradiderint [On women, who kill a child conceived in adultery, and who give over their own daughters to fornication] (Iločki statut, 43). 
"affection," although this regulation was primarily targeting women who were doing it for money, as indicated in the title. ${ }^{34}$ Was the reason for this regulation placing the moral responsibility on the one who was mature enough to know what she was doing?

It must be pointed out, however, that the statute of Ilok does not contain a single regulation directed against the prostitutes themselves. It is interesting that even if the victim of a rape was a prostitute, that fact was not an extenuating circumstance for the rapist. The punishment prescribed for raping a prostitute was the death penalty, the same for cases of honest women and girls. ${ }^{35}$ Although it is not known how often this law was enforced, the very existence of a consciousness that even in the case of a woman of suspicious morals it was still not justified to use force to coerce her into sexual intercourse is significant.

\section{Procuresses and clients}

Both the law book of Ilok and the court records of Gradec mention procuresses. One of them was Margaret, a concubine of the late George, servant of late John Kostibol, a castellan of Stupnik castle. In early 1454, Margaret was banished from the city because she had led

\footnotetext{
${ }^{34}$ Book 3, ch. 16 entitled De lenis, que virgines, et juvenculas mulieres pro pecunia obducunt [On pimps, who procure virgins, and very young women for money], states: Item, si que vetule, virgines, aut juvenculas mulieres, ad stuprum vel adulterium pro pecunia aut fauore, domicellis, clientibus, aut aliis quibuscunque personis extra matrimoium existentibus abduxerint, et hoc sufficienter contra ipsas per viam iuris vt expedit approbatum fuerit, extunc tales vetule debebunt viue in factis ligari, et in aquis vehementibus submergi [Furthermore, if some old women procure virgins, or very young women to fornication or adultery for money or favour to young gentlemen, patrons, or any other person who is not married, and their guilt would be proven enough in a legal way as is requested, then such old women should be bound alive and drowned in the deep water] (Ilocki statut, 43).

35 Book 3, ch. 22 entitled De opprimentibus publicam meretricem potencialiter [On those who violate a public whore], states: Item, si quis publicam meretricem per potenciam oppresserit, ipsa clamore facto pro illata potentia, protestata fuerit, probante sufficienti testimonio, talis sentencie capitis subiacebit, tractus in cauda equi sub patibulo decollabitur [Furthermore, if someone violates a public whore, and she protests against it shouting because of inflicted violence, after it is proven by sufficient testimony, such a perpetrator should be sentenced to capital punishment, and after being dragged on the horse tail to the scaffold, he should be beheaded] (Ilockei statut, 45). For punishment in other cases of rape see ch. 18-20 of the third book of the statute of Ilok (44-45). For different ways prostitutes were treated in cases of rapes, see: James A. Brundage, Law, Sex, and Christian Society in Medieval Europe (Chicago: Chicago University Press, 1987), 466.
} 
some girls ad meretricium circa plures concubitores, but she soon returned and was caught in the same business again. This time, the verdict highlighted that she had been caught in procuring girls more than once "for priests and other men," and she was banished once more. ${ }^{36}$ It is visible from this that the punishment for procuring girls was in practice more benign than that prescribed in the statute of Ilok.

The wife of the belt-maker Petres was also accused of procuring. The allegations against her were presented by Margaret, called Brodarica, the wife of a ship-owner, who claimed that the accused kept several prostitutes in her house. The wife of Petres vindicated herself with an oath, and it is thus not even known whether the allegations were truthful. It has to be taken into account that Margaret, on the one hand, and Petres and his wife, on the other, had been in dispute for several years before this event over allegations of theft and various insults. ${ }^{37}$ It also seems that Margaret was a problematic person to begin with. Besides Petres and his wife, she also had disputes in 1359 with Nicholas, son of John, and with a certain Farkaš. ${ }^{38}$ A year later, she had disputes with the wife of Suleh ${ }^{39}$ and in 1361 with Martin, a bootmaker. ${ }^{40}$ Therefore, it is possible that Margaret fabricated the accusation against the wife of Petres, but it could also be that she used a real-life situation against her neighbours.

A case similar to the one above is connected to the only man accused of procuring in the sources of Gradec available at present. It is the case of Janslin Krupičić, whom John Galga accused of keeping prostitutes in $1363 .{ }^{41}$ The result of the trial is not extant, and therefore we do not know whether the accusation proved to be true or not. However, it should be said that Janslin was a person frequently encountered in court records in different cases regarding thefts, injuring others, or for other unknown reasons against different people in both roles of the accuser and the accused. ${ }^{42}$ Since it was certainly the case of a contentious person engaged in enmity with many others, it is possible

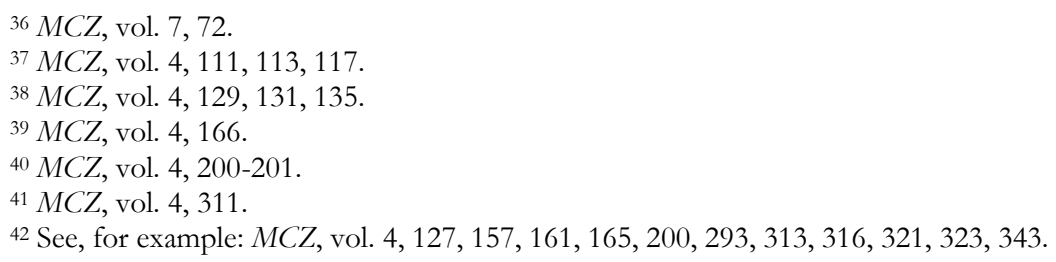


that the accusation was false, but it could also be that Janslin was really engaged in the organisation of prostitution.

Widows were often involved in organizing prostitution. This can be explained by the deterioration of their finances after the deaths of their husbands and the need to earn a living. The sources mention that when widows kept prostitutes and this was proven to be true, they paid fines. ${ }^{43}$ It is interesting to note that in these cases fines were employed rather than banishment from the city. This may show a certain consideration by the city authorities and their understanding of the problem those women faced from being left without a husband.

In the end, we may briefly reflect on men who used the services of prostitutes. In court records, they were mentioned mostly in general terms, as, for example, in the trial against Margaret, the concubine of the late George, when she was accused of procuring girls to priests and other men. ${ }^{44}$ One of the rare clients mentioned by name was a priest named Martin who was, after being caught with the prostitute Granda, handed to ecclesiastical authorities who subsequently punished him. ${ }^{45}$ The reason for this punishment is likely that the city community did not tolerate actions of ecclesiastical persons which they might have tolerated in cases of laymen. On the particularly negative attitude of sexual relations between prostitutes and priests is evidenced by common insults which included phrases such as meretrix presbitorum or meretrix monachorum. ${ }^{46}$

\section{Final remarks}

In summarising the cases mentioned above, we can see that prostitution was not limited only to members of the lowest layer of society and people on the margins, but it also included members of other social strata who sometimes used prostitution as a means of additional income. The fact that there are not many suits concerning prostitutes themselves in the court records of Gradec also can suggest that there existed a certain tolerance towards prostitution. Even though prostitution was considered as something wrong and the penalties were

\footnotetext{
${ }^{43} M C Z$, vol. 4, xxvi.

${ }^{44} M C Z$, vol. 7, 72 .

${ }^{45} M C Z$, vol. 7, 326.

${ }^{46}$ For example, see: $M C Z$, vol. 8, 95, 145.
} 
severe if the case came in front of the court, it seems that the community often looked the other way concerning prostitution.

\section{References}

\section{Primary sources}

Bak, János M., György Bónis, James Ross Sweeney, Leslie S.

Domonkos. The Laws of the Medieval Kingdom of Hungary. Decreta regni mediaevalis Hungariae, vol. 1. Idyllwild: Charles Schlacks, Jr., Publisher, $1999^{2}$.

Klaić, Vjekoslav. Statut grada Zagreba od 1609. i njegova reforma god. 1618. [The Statute of the City of Zagreb of 1609 and its Reform of 1618]. Zagreb: Grad Zagreb, 1912.

Schmidt, Rudolf. Statut grada Iloka irgodine 1525. [The statute of the city of Ilok from the year 1525] (henceforth: Ilockei statut). Monumenta historico-juridica Slavorum Meridionalium, vol. 12. Zagreb: JAZU, 1938.

Tkalčić, Ivan Krstitelj. Povjestni spomenici slob. kralj. grada Zagreba. Monumenta historica liberae regiae civitatis Zagrabiae, vol. 1-11. Zagreb: Grad Zagreb, 1889-1905.

\section{Secondary sources}

Apostolova Maršavelski, Magdalena. Izpravne prošlosti Zagreba (13.-16. stoljece) [From the legal history of Zagreb]. Zagreb: Školska knjiga, 1998.

Brundage, James A. Law, Sex, and Christian Society in Medieval Europe. Chicago: Chicago University Press, 1987.

Karbić, M. "The 'Illicit Love' in Medieval Slavonian Cities." In Love, Marriage and Family Ties in the Middle Ages, ed. Isabel Davis, Miriam Müller, Sarah Rees. International Medieval Research 11, 331-340. Turnhout: Brepols, 2003.

Klaić, Nada. Zagreb u srednjem vijeku [Zagreb in the Middle Ages]. Zagreb: Sveučilišna naklada Liber, 1982.

Margetić, Lujo. Hrvatsko srednjovjekovno obiteljsko i nasljedno pravo [Croatian medieval family and inheritance law]. Zagreb: Narodne novine, 1996. 
. "Iločka pravna knjiga (tzv. Iločki statut)" [Ilok's law book (the so-called statute of Ilok)], Zbornik Pravnog fakulteta u Zagrebu 44/1-2 (1994): 93-116.

Mazo Karras, Ruth. Prostitution and Sexuality in Medieval England. New York - Oxford: Oxford University Press, 1996.

Mertanová, Štefánia. Ius tavernicale: stúdie o procese formovania práva tavernickych miest v etapách vývoja taverniickeho súdu v Uhorsku (15.-17. stor.) [Ius tavernicale: Studies on the formation process of the law of tavernical cities through the stages of development of the tavernical court in Hungary (15 ${ }^{\text {th }}-17^{\text {th }}$ centuries). Bratislava: Slovenskej Akademie Vied, 1985.

Miljan, S. "Siromasi kasnosrednjovjekovnoga Zagreba" [The poor of late-medieval Zagreb]. Povijesni prilozi 42 (2012): 81-102.

Ravančić, G. "Prostitucija u kasnosrednjo-vjekovnom i renesansnom Dubrovniku" [Prostitution in late medieval and Renaissance Dubrovnik]. In Gradske marginalne skupine u Hrvatskoj kroz srednji vijek $i$ ranomoderno doba [Urban marginal groups in Croatia in the Middle Ages and the early modern period], Biblioteka Dies historiae, vol. 1, 89-105. Zagreb: Hrvatski studiji, 2004.

Shek Brnardić, T. "Tavernik, tavernikalni sud i tavernikalno pravo" [Tavernicus, tavernical court and tavernical law). Arbivski vjesnik 40 (1997): 179-198.

Vitek, Darko. Drustueni odnosi u srednjovjekovnom Iloku prikazani Iločkim statutom iz 1525. godine [The social relations in medieval Ilok according to the statute of Ilok from 1525]. MA Thesis. Zagreb: Filozofski fakultet, 2000.

. "Struktura i izvorište teksta Iločkog statuta" [The structure and origin of the text of the statute of Ilok]. Scrinia Slavonica 1 (2001): 404-420.

Zdravčević, Andrija. Iločki statut iz 1525. godine i njegova nasljednopravna regulacija [The statute of Ilok from 1525 and its hereditary-legal regulation]. PhD Thesis. Osijek: Pravni fakultet, 1992. 